Revue

de Sémantique

et Pragmatique
Revue de Sémantique et Pragmatique

40 | 2016

Exclamation et intersubjectivité

\title{
Exclamations as multi-dimensional intersubjective items
}

\section{Richard Faure}

\section{(2) OpenEdition \\ 1 Journals}

\section{Electronic version}

URL: http://journals.openedition.org/rsp/277

DOI: $10.4000 /$ rsp. 277

ISSN: $2610-4377$

\section{Publisher}

Presses universitaires d'Orléans

\section{Printed version}

Date of publication: 1 March 2017

Number of pages: 7-15

ISSN: 1285-4093

\section{Electronic reference}

Richard Faure, «Exclamations as multi-dimensional intersubjective items », Revue de Sémantique et Pragmatique [Online], 40 | 2016, Online since 04 August 2017, connection on 25 September 2020.

URL : http://journals.openedition.org/rsp/277 ; DOI : https://doi.org/10.4000/rsp.277 


\title{
EXCLAMATIONS AS MULTI-DIMENSIONAL INTERSUBJECTIVE ITEMS
}

\author{
Richard Faure
}

Université Côte d'Azur, CNRS, BCL, France

\section{EXCLAMATION AS AN ISOLATING ACT}

Studies on exclamation usually start with the remark that this area is little explored. This is not true anymore. We now have a good deal of works on this topic, some of which are particularly influential, including Culioli (1974), Elliott (1974), Milner (1978), Martin (1987), Michaelis and Lambrecht (1996), d'Avis (2001), Zanuttini and Portner (2003), Castroviejo Miró (2006), Rett (2011). We know that exclamations have the following properties:

- They have an affective (emotive, expressive) dimension, linked to the speaker's counter-expectations or high involvement.

- They share some, but not all formal and interpretive properties with both assertions and interrogations.

- They are factive, carry information that is evident (be it a presupposition, a conventional implicature, or something else).

- They often look like incomplete sentences (reduced form of interrogative clauses, relatives clauses, NPs...).

- They involve high degree.

- Their contour is often fuzzy. From one author to another, exclamations include all utterances with a high level of emotivity, or are limited to some types of constructions. 
On the basis of these properties, some scholars have attempted to give a broad definition of the exclamative speech act. ${ }^{1}$ According to Rett (2011), « for the utterance of an exclamation to be expressively correct, its content must be salient, and the speaker must find this content surprising. $»^{2}$ One can see that the speaker and his/her feeling are central in this definition.

Some authors go a step further and claim that exclamations are subjective. As pointed out in Verhagen $(2005,5)$, subjective means either 'not objective' or 'not shared'. The 'not-objective' view is that exclamations are the extreme degree of self-expression. The 'not-shared' sense implies that the hearer is excluded or marginalized, (see Michaelis and Lambrecht 1996's deictic anchoring, Marandin 2008's and Badan and Cheng 2015's ego-evidentiality). Often mentioned is the impossibility for exclamations to answer or to be answered (Castroviejo Miró 2008). Exclamations might have no function in the information process, contrary to interrogations and assertions. This double isolation is tied to the speaker's emotive state which cuts him/her from the context. For example, Milner $(1978,342)$ claims that « exclamatives stand on their own and do not call for a reaction from the hearer. (...) The presence of an actual hearer is not even obligatorily assumed. $»^{3}$

\section{EXCLAMATION IN CONTEXT}

\subsection{EXCLAMATIONS ARE CONTEXT SENSITIVE}

Still, exclamations have a verbal, meaningful content (they are not mere expressions of emotion, as interjections are sometimes taken to be), i.e. they at least comment on what triggered the speaker's emotion and his/her exclamation (the evaluative dimension was repeatedly noticed in the literature). In the Greek example (1), from Euripides' Hecuba, the Chorus is uttering a judgment on Hecuba's tough suggestion to Agamemnon, but it also aims to defuse the tension and make the hearers relax. This utterance then also constitutes an indirect speech act.

${ }^{1}$ Most studies focus on some type of exclamations and do not provide a definition applying to all types.

${ }^{2}$ She then divides exclamations into (declarative) exclamations and exclamatives. According to her, only exclamatives involve high degree.

${ }^{3}$ My translation : « [Les exclamatives] valent pour elles-mêmes, et n'appellent aucune réponse de la part de l'interlocuteur. (...) La présence d'un interlocuteur réel n'est même pas nécessairement supposée. » Milner, however, acknowledges that exclamatives with negation are made to attract the hearer's attention, but attributes this capacity to the negation, not to the exclamatives themselves (p. 347). 
(1) Pheu

$\mathrm{Oh}$

khrêstôn

$$
\text { pheu! }
$$

oh

of.good-gen.pl occasions give
Brotoisin hôs ta

to.mortals how the

logôn.

always speeches-gen.pl

«Bravo! How the good behaviors always suggest good speeches to the mortals! » (E.Hec.1238)

All this means that exclamations cannot be satisfactorily described if the context is not taken into account. This must involve a treatment of both the descriptive (objective) part of the message and the possible presence of a listener. Thus, Castroviejo Miró (2008) admits that exclamations minimally have a Context Change Potential of the Common Ground by the very fact that they are speech acts. Rett (2011) shows that in order to be surprising, a degree must exceed not only the speaker's expectations, but also a contextual, conventional standard. ${ }^{4}$ Exclamations also play a role in the argumentative structuring of the discourse as well as in the conversational strategies, perhaps their most often noticed property (Martin [1987, 94], Eggs [2008, 303]). ${ }^{5}$

\subsection{EXCLAMATIONS IN DIALOGS}

If we take this idea a step further, we can hypothesize that the interaction with the context involves an interaction between the speaker and the hearer, i.e. an intersubjective dimension of the exclamation. We have evidence that it is necessary to investigate this topic. For example, the acquaintance of exclamations with definiteness points towards a knowledge shared by the conversation participants. Moreover, exclamations trigger interactions. Let us have a look at Example (2). In this scene from Euripides' Alcestis, the king Admetus, whose wife has just died to save him, complains about the fate. He uses a nominal and a wh-exclamative side by side.

(2) Admetos. ô tlêmôn egô/ hôs arti penthous toûde geuomai pikrou Oh luckless me how now grief this I.taste bitter

Khoros. Egô men ouk ekhoim'an eu legein tukên. I on.the.one.hand not could well speak fate Khrê d' hêtis esti karterein theou dosin. necessary on.the.other.hand whatever is to.endure of.god gift « Admetus. Oh luckless me! How bitter the grief that I now taste! Chorus. I cannot call Fate kind. But one must endure what the god gives, whatever it is. » (E.Alc.1068-1071)

${ }^{4}$ See also Kerfelec $(2009,236)$.

${ }^{5}$ For example, in the following sentence, adapted from Eggs (2008), the exclamation serves as a justification: you should hire her. She's so clever! 
Interestingly, the Chorus's reaction is twofold (note the use of men/de 'on the one hand, on the other hand'). In the first part, the Chorus comments on the content of Admetus' exclamation and admits that it is true. However, in the second part, it expresses its disagreement with Admetus' attitude regarding this fact. This example shows that 1) exclamations are not independent from the context (they can be followed up on), 2) they are multi-dimensional objects, opening up multiple possibilities of interactions, on both the linguistic and the psychological side.

This relation to the hearer is taken into account in Chernilovskaya (2014)'s definition, according to which an exclamation is a speech act designed for pointing out the noteworthiness of a phenomenon to the hearer (thus adding to the Common Ground the proposition that the content of the exclamation is noteworthy).

However, so far, only Kerfélec (2009, Chapter 4$)^{6}$ has delved in depth into this matter, maybe due to its psychological flavor linguists are not at ease with. According to her, the core meaning of the exclamation is that both 1) the speaker cannot tell the degree reached by a quality or a quantity that s/he noticed, and 2) s/he cannot help but express that s/he cannot tell: « This paradox necessarily gives rise to a dialogical and original functioning, whose description is not easy. » « The exclamation appears as a personal and wild reaction to an obvious and objective property to which the hearer must adhere. $»^{7}$

To sum up, the linguist must inquire both the stand the conversation participants take on a situation that they must admit (the objective part), and the encounter of two subjectivities and how it is managed. When talking about intersubjectivity, we are talking about shared subjectivity, i.e. about subjects whose viewpoints, construals of situations and intentions are mutually and simultaneously considered (Verhagen 2005). ${ }^{8}$ This means that the socio-psychological dimension of language must not be turned away from, in particular because of the emotivity that is involved. The following questions arise:

${ }^{6}$ The title, based on wordplay, is difficult to translate « Fonctionnement en discours: la langue a la parole. »

7 « De ce paradoxe naît forcément un fonctionnement dialogique original dont la description n'est point aisée. » (p. 225) « [l'exclamation] se donne pour une réaction personnelle et incontrôlée à une propriété objective évidente à laquelle L2 ne peut donc qu'adhérer. » (p. 252)

${ }^{8}$ Note that « even in the absence of an actual addressee, a speaker (for example, one making a note in a personal diary) is committed to the assumption that her utterance is in principle interpretable by someone else sharing the knowledge of certain conventions. The idea that some utterance could in principle only be interpretable for a single individual makes the idea that it is an instance of language void. » (Verhagen $(2005,7-8)$ ). 
- Are exclamations only disrupters or do they serve to establish a connection with others? Possibly beyond empathy or emotive contagion?

- Are exclamations conventionalized? Are there exclamatory schemes? Are they part of conversational patterns of bigger size?

- Can they serve as reactions (answers or replies)? ${ }^{9}$ Do they trigger specific reactions?

- Are they built on the image the speaker has of the hearer? Are they conscious means for the speaker to build an image of him/herself or to influence the others' construals?

\section{EXCLAMATIONS AS INTERSUBJECTIVE ITEMS}

In this special issue of the Revue de Sémantique et de Pragmatique, the authors try to answer some of these questions by mostly building on new naturalistic data, from uncommon corpora, a route rarely explored in the study of exclamations (parliamentary debates, TV shows, press articles, recordings of everyday conversations, forum discussions). Several inquiry paths are taken, the intersubjectivity playing a role (at least) at three levels in exclamations: in their Context Change Potential, in the way the speaker takes into account the environment in which s/he exclaims, and in the impact the speaker may expect from his/her exclamation.

First, an intersubjective part can be needed in the general definition of the exclamative speech act, for example by including a will of adjustment of the world to the words (as in injunction) to take a famous searlian expression. ${ }^{10}$ This could be the case if we assume that by uttering an exclamation the speaker wants the hearer to share his/her feelings.

In « Exclamatives, Normalcy Conditions and Common Ground », Franz d'Avis further explores what counter-expectation means, a concept assumed to be the basis of the exclamative meaning, and what impact it has on the conversation conditions. He suggests that counter-expectation is related to what the speaker finds normal, which he dubs « Normalcy ». Every exclamation is endowed with an exclamative accent that, like Focus, opens up a set of alternatives (à la Rooth 1985). These alternatives form the speaker's normalcy conceptions. F. d'Avis claims that it is part of the felicity conditions of the exclamative speech act that the Common Ground is updated with the proposition that the

${ }^{9}$ In the sense of Kerbrat-Orecchioni $(1995,206)$ : answers give a piece of information required by the preceding utterance; replies comment on it.

${ }^{10}$ As Merin and Nikolaeva $(2008,9)$ put it: « The exclamation, we take it, is intended to induce in the hearer an attitudinal orientation change that mirrors a change ostensibly undergone by the speaker. » 
proposition underlying the exclamation is not part of the speaker's Normalcy conceptions.

Second, the linguist can address the multi-dimensional character of exclamations. They are not only information about the speaker's state of mind. They also construct an image of the environment by commenting on their stimulus, or on the image the speaker has of the hearer.

In «The deictic dimension of exclamations: On the use of wh-exclamatives in German face-to-face interaction, » Martin Pfeiffer examines an interesting property of exclamations. They are reactions to an (unexpected) stimulus, but, by naming it, they also point towards the object that triggers them, be it visually, anaphorically or through imagination. This very deictic capacity gives them an extra, intersubjective dimension, since it is meant to let the addressee know what is going on.

In her article « De l'admiration à l'exclamation. Élaboration d'un concept ou construction d'un problème ?, » Cendrine Pagani-Naudet addresses the history of the concept of « exclamation. » She shows that exclamation was first conceived of as an intersubjective phenomenon at the time when grammar and rhetoric were completely separate. In the 16th and 17 th Centuries there was a division of labor between two terms. Grammarians described a phenomenon of admiration only in order to reject it outside the domain of grammar as being closer to a yell than to a linguistic expression. On the other hand, exclamation was used in the rhetorical domain, which took into consideration its intersubjective side, since exclamations were seen as means to act on the addressee. It is only in the 18th Century, when grammarians started to care about the phenomenon of exclamation that intersubjectivity disappeared from the descriptions, a take that has lasted until recently. Cendrine Pagani-Naudet attributes this turn to the change in use of the grammar books: while in the Renaissance, they were designed for people learning French, i.e. to help them interact with others, in the Enlightenment they targeted native speakers and the way they can best express their feelings.

Anne Larrory-Wunder («Exclamation et intersubjectivité en allemand ») starts with the remark that exclamations have a comment function, often pointing to a divergence in belief between the speaker and the hearer. This means that, when exclaiming, the speaker considers, or even constructs an image of the hearer's viewpoint, even if to express his/her disagreement. This kind of cooperation is perceptible in many idiomatic German constructions. Interestingly, Anne Larrory-Wunder shows that some exclamative constructions are employed as injunctions, i.e. are indirect speech acts.

«Exclamation et intensité intersubjective dans un forum d'apprentissage à distance », by Joséphine Rémon, focusses on exclamation marks in a forum 
where English learners discuss. These signs are mostly used by the writer to add expressivity to every type of utterances, always in relations with others. There is however a scale going from the addition of intensity to lend weight to the writer's statement (in this case, there is interaction, but the addressee is only taken as a passive receiver), to the contradiction of the addressee's expectations or the preservation of the writer's or the other's face (in the sense of Goffman 1974). Except for the cases of mere intensity, counter-expectation is always present. Interestingly, it is often shared with, or even the exclusive attribute of the addressee.

Third, an important effect that exclamations have is that they are disruptive. They often break the conversation flow. They can be viewed as expressions of misunderstanding and calls for repair. Accordingly, they could enter in schemes like those developed in Schegloff (1992) for « defense » and « management » of intersubjectivity. But they also initiate conciliations.

Naomi Truan's article (« On the Pragmatics of Interjections in Parliamentary Interruptions ») studies parliamentary debates in the Bundestag. This is a vantage point to observe interruptions with interjections and how expressive utterances can be taken as parts of the conversation on a par with other devices. They often open a new turn in the conversation (except for approval interjections).

Some languages have several forms marked as exclamatives. This is the case of Gbaya. In her paper " le rôle de l'énoncé exclamatif en gbaya, une langue oubanguienne de R.C.A, » Paulette Roulon-Doko shows that the factor responsible for the distribution of the two exclamative forms is intersubjectivity. This goes along with the nature of the evaluation accompanying the exclamation. $(N \grave{\varepsilon}+g \grave{e})$-exclamations are intersubjective and specialize in disagreement (between the two conversation participants). On the other hand, (nغे+ADV)exclamations are speaker-centered and mark a positive evaluation. Besides, mere surprise is expressed with a specific form, called 'mirative.'

Mirta Desnica focusses on so-exclamatives in «Une manière «tendance » de s'exclamer avec l'autre : l'exclamative en SO dans la presse française. » She explores the intersubjective potential of this well-known type of exclamation. According to her, uttering an exclamative in so (at least in magazines and newspapers) yields identification between subjects, between the journalist and his/her reader that both share this trendy and informal means to characterize something as resembling a typical referent. 


\section{RÉFÉRENCES}

Badan, L. and Cheng, L. L.-S. (2015), « Exclamatives in Mandarin Chinese », Journal of East Asian Linguistics 24.4, 383-413.

Castroviejo Miró, E. (2006), «Wh-exclamatives in Catalan », PhD Dissertation.

Castroviejo Miró, E. (2008), « Deconstructing Exclamations », Catalan Journal of Linguistics 7.41-90.

Chernilovskaya, A. (2014), Exclamativity in Discourse. Exploring the exclamative speech act from a discourse perspective, Utrecht: LOT.

Culioli, A. (1974), «A propos des énoncés exclamatifs », Langue française 22.1, 6-15.

d'Avis, F. J. (2001), Über >w-Exklamativsätze < im Deutschen, Tübingen: Niemeyer.

Eggs, E. (2008), « Le Pathos dans le discours - exclamation, reproche, ironie », in Emotions et Discours. L'usage des passions dans la langue, Rinn, M. (ed.), Rennes: Presses Universitaires de Rennes, 291-320.

Elliott, D. E. (1974), « Toward a grammar of exclamations », Foundations of Language 11.2, 231-246.

Goffman, E. (1974), Les rites d'interaction, Paris: les Éditions de Minuit.

Kerbrat-Orecchioni, C. (1995), Les interactions verbales, Vol. 1, Deuxième édition mise à jour, Paris: Armand Colin.

Kerfélec, V. (2009), L'exclamation en français et en anglais. Formes, sens, effets, Aix-en-Provence: Publications de l'université de Provence.

Marandin, J.-M. (2008), « The exclamative clause type in French », in Proceedings of the 15th international conference on head-driven structure grammar, Müller, S. (ed.), Stanford: CSLI, 436-456.

Martin, R. (1987), « La phrase exclamative et les univers de croyance », Langage et croyance, les univers de croyance dans la théorie sémantique, Chap. VII, Paris: Madarga.

Merin, A. and Nikolaeva, I. (2008), « Exclamative as a Universal Speech Act Category: A case study in decision-theoretic semantics an typological implications », Ms. University of Konstanz and SOAS London University.

Michaelis, L. A. and Lambrecht, K. (1996), « The exclamative sentence type in English », in Conceptual Structure, discourse and language, Goldberg, A. (ed.): 375-389.

Milner, J. C. (1978), De la syntaxe à l'interprétation, Paris: Le Seuil.

Rett, J. (2011), « Exclamatives, degrees and speech acts », Linguistics and Philosophy 34.411-442.

Rooth, M. (1985), « Association with focus», $\mathrm{PhD}$ dissertation. University of Massachusetts . 
Schegloff, E. A. (1992), « Repair After Next Turn: The Last Structurally Provided Defense of Intersubjectivity in Conversation », The American Journal of Sociology $97.5,1295-1345$.

Verhagen, A. (2005), Constructions of Intersubjectivity. Discourse, Syntax, and Cognition, Oxford-New York: Oxford University Press.

Zanuttini, R. and Portner, P. (2003), « Exclamative clauses: At the syntax-semantics interface », Language 79.1, 39-81. 